\title{
CHEMICAL FEATURES OF BIOTITES FROM METAMORPHIC AND GRANITIC ROCKS OF THE YANAI DISTRICT IN THE RYOKE BELT, JAPAN
}

\author{
HIROJI HONMA
}

Institute for Thermal Spring Research, Okayama University, Misasa, Tottori-Ken, Japan

\section{INTRODUGTION}

Composition of biotites in metamorphic rocks has been discussed by many authors in terms of bulk composition and metamorphic grade of host rocks (e.g. Miyashiro, 1956; Engel and Engel, 1960; Ōki, 1961; Hayama, 1964; Wenk, 1970). It has been shown that $\mathrm{Fe}$ in biotite increases in general with increasing metamorphic grade, whereas $\mathrm{Ti}, \mathrm{Mg}$ and $\mathrm{Al}$ decrease. However, the behaviours of these elements in metamorphic processes are not known in detail.

Biotites from some Caledonian calcalkaline plutonic rocks follow a well-defined trend in the $\mathrm{FeO}-\mathrm{MgO}-\mathrm{Al}_{2} \mathrm{O}_{3}$ diagram (Nockolds and Mitchel, 1948). The ratio $\mathrm{Al}_{2} \mathrm{O}_{3}:(\mathrm{MgO}+$ total $\mathrm{Fe}$ as $\mathrm{FeO})$ in biotites from calc-alkaline igneous rocks is determined by their paragenesis (Nockolds, 1947) and there is a general increase in the Al content of biotites with increasing acidity of the host rocks. However, some intrusions show a reverse trend and no agreement has been reached about the precise bearings of the $\mathrm{Al}$ content of biotites on magmatic processes.

Shibata et al. (1966) reported chemical analyses of biotites from metamorphic and granitic rocks of Japan and suggested that the high Al contents of biotites from some Ryōke granitic rocks are due to contamination by pelitic sediments.

Majority of reported analyses of biotites from igneous rocks shows a general decrease in the $\mathrm{Mg} / \mathrm{Fe}$ ratio with increasing acidity of the host rocks. However, reverse is the case with many intrusions (e.g. see Murakami, 1969; Kanisawa, 1972). Wones and Eugster (1965) determined experimentally the composition of biotites co-existing with sanidine and magnetite under varying conditions of $\mathrm{f}_{\mathrm{H}_{\mathbf{1}} \mathrm{O}}, \mathrm{f}_{\mathrm{O}_{2}}$ and temperature and suggested that biotites crystallizing from a magma may follow either iron-rich or magnesium-rich trend, depending upon $f_{o}$, during cooling.

Thirty-one biotites from metamorphic and granitic rocks of the Yanai district in the Ryōke belt, Southwest Honshū, Japan, have been chemically analysed as a part of the geochemical, mainly oxygen isotopic, study of the rocks. All the samples are believed to have been formed under roughly a uniform P-T condition and, hence, differences in their chemical compositions and parageneses would reflect those in the chemistry of their host rocks. In the present paper, this will be shown to be the case. Condition of formation of the meta- 
morphic and granitic rocks of this district will also be discussed from the results. This paper is complementary to the previous one that described the major element chemistry of these rocks (Honma, 1974).

\section{Geological Settings}

An outline of the geology of the area, a brief description of the host rocks of the most biotites of the present study and a geological map showing sampling localities are available in the previous paper (Honma, 1974).

The granitic rocks including migmatites are grouped into the-syntectic layered (Kojima and Okamura, 1968) and discordant rock types. The former (the Ōbatake and Gamano layered granodiorites and the Okiura layered granite) are intimately associated with amphibolite and sedimentary gneiss. Though it may be granted that the main facies of the Obatake and Gamano layered granodionites originated from a magma of the equivalent composition, petrological and structural evidence shows that "granitization" in a broad sense took place in the formation of these rocks (Okamura, 1957). However, such "granitization" including metasomatic formation of some minor facies of these layered rocks could occur as a result of intense interaction between the granitic magma and surrounding sedimentary gneiss or amphibolite (Honma, 1974).

The host rocks of the biotites of the present study are from the migmatite zone of Nureki (1960) with two exceptions (YN28 and YN38, from the transitional zone) and include amphibolites, pelitic and siliceous gneisses and granitic rocks. Mineral paragenesis within each kind of these metamorphic rocks is rather uniform and the layered granitic rocks are intimately associated with metamorphic rocks, both forming thin layers intercalated by each other. Oxygen isotopic equilibrium temperatures of sevral mineral pairs from these rocks fall in a narrow range from $600^{\circ}$ to $700^{\circ} \mathrm{C}$ (Honma, 1974, unpublished). These facts appear to suggest that most biotites studied were formed under roughly a constant P-T condition.

$\mathrm{YN1} 1-1, \mathrm{YN} 8-1$ and $\mathrm{YN} 24$ are from rocks which were not previously studied. The first two are from siliceous banded gneisses of chert origin and are much the same as OS2-4 in occurrence and petrography. YN24 is a K-feldspar porphyritic two-mica granite named as the Kibe granite, one of the younger (discordant) Ryōke granites (Okamura, 1957). The chemical composition of the Kibe granite was given by Shibata et al. (1960). In the previous paper, $\mathrm{YN15}$, an intrusive and garnet-bearing biotite leucogranite, was included into the Obatake and Gamano layered granodiorites. But it is similar in petrography and chemistry to the Okiura layered granite and is treated in this paper as a member of this granite.

\section{EXPERIMENTAL}

Separation of biotites was made by panning and repeated passing in a Frantz magnetic separator. The biotite samples analysed were better than 97 per cent in purity.

Analytical procedures are based on the method proposed by Ōki et al. (1962) using ion exchange columns. Alkalies were separated from each other and determined volumetrically. Weight loss by ignition corrected for oxidation of ferrous iron was taken as $\mathrm{H}_{2} \mathrm{O}^{+}$. Replicate partial analyses 
Table 1

Composition of

\begin{tabular}{|c|c|c|c|c|c|c|c|c|}
\hline No. & 1 & 2 & 3 & 4 & 5 & 6 & 7 & 8 \\
\hline Specimen & Os $2-4$ & YN I-I & YN 8-1 & YN 38 & YN 28 & os $2-1$ & os $8-2$ & OS $7-1$ \\
\hline $\mathrm{SiO}_{2}$ & 34.17 & 33.99 & 34.70 & 34.67 & 33.03 & 34.03 & 34.40 & 34.08 \\
\hline $\mathrm{TiO}_{2}$ & 2.31 & 3.46 & 2.76 & 3.30 & 3.28 & 2.66 & 3.79 & 3.97 \\
\hline $\mathrm{AI}_{2} \mathrm{O}_{3}$ & 18.34 & 18.37 & 18.86 & 19.33 & 18.86 & 19.49 & 14.42 & 14.96 \\
\hline $\mathrm{Fe}_{2} \mathrm{O}_{3}$ & 3.73 & 2.80 & 2.46 & 1.81 & 0.44 & 3.17 & 2.18 & 2.28 \\
\hline FeO & 15.00 & 14.90 & 16.17 & 19.53 & 18.96 & 17.73 & 19.37 & 20.19 \\
\hline Mno & 0.58 & 0.34 & 0.51 & 0.11 & 0.21 & 0.50 & 0.29 & 0.16 \\
\hline $\mathrm{MgO}$ & 9.15 & 9.66 & 8.40 & 6.82 & 9.41 & 6.99 & 8.64 & 8.85 \\
\hline $\mathrm{CaO}$ & 0.11 & 0.37 & 0.33 & 0.58 & 0.75 & 0.39 & 0.95 & 0.54 \\
\hline $\mathrm{Na}_{2} \mathrm{O}$ & 0.46 & 0.32 & 0.64 & 0.34 & 0.64 & 0.48 & 0.50 & 0.22 \\
\hline $\mathrm{K}_{2} \mathrm{O}$ & 9.55 & 8.90 & 9.94 & 8.62 & 9.16 & 9.06 & 9.21 & 9.37 \\
\hline $\mathrm{H}_{2} \mathrm{O} \quad(+)$ & 4.96 & 5.43 & 4.18 & 4.30 & 3.98 & 4.34 & 3.86 & 4.34 \\
\hline $\mathrm{H}_{2} \mathrm{O}(-)$ & 0.62 & 0.93 & 0.69 & 0.72 & 0.48 & 0.78 & 1.32 & 0.97 \\
\hline $\mathrm{P}_{2} \mathrm{O}_{5}$ & 0.01 & 0.01 & 0.00 & 0.00 & 0.01 & 0.00 & 0.01 & 0.01 \\
\hline Total & 98.99 & 99.48 & 99.64 & 100.13 & 99.21 & 99.62 & 98.94 & 99.94 \\
\hline & & & & & & Number & of Atoms & on Basj \\
\hline Si & 5.17 & 5.20 & 5.28 & 5.26 & 5.11 & 5.20 & 5.38 & 5.28 \\
\hline $\mathrm{Al}^{\mathrm{IV}}$ & 2.83 & 2.80 & 2.72 & 2.74 & 2.89 & 2.80 & 2.62 & 2.72 \\
\hline $\mathrm{A}_{1} \mathrm{VI}$ & 0.44 & 0.51 & 0.66 & 0.72 & 0.55 & 0.71 & 0.03 & 0.03 \\
\hline $\mathrm{T} i$ & 0.26 & 0.40 & 0.32 & 0.37 & 0.38 & 0.31 & 0.44 & 0.46 \\
\hline $\mathrm{Fe}^{3+}$ & 0.42 & 0.32 & 0.28 & 0.20 & 0.05 & 0.36 & 0.25 & 0.26 \\
\hline $\mathrm{Fe}^{2+}$ & 1.90 & 1.91 & 2.06 & 2.48 & 2.46 & 2.27 & 2.53 & 2.62 \\
\hline $\mathrm{Mn}_{\mathbf{n}}$ & 0.07 & 0.04 & 0.07 & 0.01 & 0.03 & 0.06 & 0.04 & 0.02 \\
\hline $\mathrm{Mg}$ & 2.06 & 2.20 & 1.90 & 1.54 & 2.17 & 1.59 & 2.01 & 2.04 \\
\hline $\mathrm{Ca}$ & 0.02 & 0.06 & 0.05 & 0.09 & 0.12 & 0.06 & 0.16 & 0.09 \\
\hline $\mathrm{Na}$ & 0.13 & 0.09 & 0.19 & 0.10 & 0.19 & 0.14 & 0.15 & 0.07 \\
\hline $\mathbf{K}$ & 1.84 & 1. 74 & 1.93 & 1.67 & 1.81 & 1.76 & 1.83 & 1.85 \\
\hline $\mathrm{OH}$ & 5.01 & 5.55 & 4.25 & 4.36 & 4.11 & 4.42 & 4.02 & 4.49 \\
\hline
\end{tabular}

1-3 : From siliceous gneiss 4-5 : From pelitic gneiss 6: From pelitic gneiss, partly migmatitic 7-9: From migmatitic facies of the Ōbatake and Gamano layered granodiorites associated with amphibolite 15.16: granodiorites

were made for a biotite sample from a very leucocratic granite (YN6-1).

\section{RESULTS AND DISGUSSION}

Biotite analyses and atomic ratios of cations and hydroxyl ion calculated on the basis of $24(\mathrm{O}, \mathrm{OH})$ are presented in Table 1. In most biotites, the sum of twelvecoordinated large cations, $\mathrm{Ca}, \mathrm{Na}$ and $\mathrm{K}$, is close to the ideal number of 2.00. Some 
Biotites

\begin{tabular}{|c|c|c|c|c|c|c|c|}
\hline 9 & 10 & 11 & 12 & 13 & 14 & 15 & 16 \\
\hline OS 11 & YN 3-1 & os 1 & os $8-1$ & $Y N 10$ & YN $3-2$ & OS10-2 & YN 30 \\
\hline 35.22 & 35.12 & 33.84 & 34.48 & 35.44 & 33.38 & 33.94 & 35.01 \\
\hline 3.60 & 3.90 & 3.70 & 3.79 & 3.86 & 3.80 & 4.26 & 2.80 \\
\hline 14.56 & 14.79 & 14.84 & 15.20 & 14.01 & 16.27 & 16.10 & 14.71 \\
\hline 1.70 & 2.01 & 4.51 & 2.81 & 1.94 & 2.33 & 2.74 & 2.35 \\
\hline 17.66 & 18.06 & 19.85 & 19.05 & 19.59 & 21.06 & 20.55 & 22.44 \\
\hline 0.23 & 0.22 & 0.40 & 0.45 & 0.40 & 0.41 & 0.34 & 0.56 \\
\hline 11.26 & 10.05 & 6.78 & 8.14 & 8.31 & 6.81 & 7.94 & 7.32 \\
\hline 0.77 & 0.44 & 0.67 & 0.17 & 1.19 & 0.29 & 0.34 & 0.57 \\
\hline 0.81 & 0.37 & 0.28 & 0.34 & 0.02 & 0.01 & 0.21 & 0.35 \\
\hline 8.91 & 8.80 & 8.92 & 9.31 & 9.16 & 9.10 & 9.06 & 9.36 \\
\hline 3.67 & 4.83 & 4.49 & 4.18 & 3.70 & 4.72 & 4.10 & 3.98 \\
\hline 0.85 & 0.97 & 1.46 & 1.56 & 1.47 & 1.21 & 0.73 & 0.49 \\
\hline 0.00 & 0.01 & 0.02 & 0.01 & 0.00 & 0.00 & 0.00 & 0.01 \\
\hline 99.24 & 99.57 & 99.76 & 99.49 & 99.09 & 99.39 & 100.31 & 99.95 \\
\hline \multicolumn{8}{|c|}{$(\mathrm{O}, \mathrm{OH})=24$} \\
\hline 5.45 & 5.35 & 5.29 & 5.38 & 5.58 & 5.20 & 5.24 & 5.48 \\
\hline 2.55 & 2.65 & 2.71 & 2.62 & 2.42 & 2.80 & 2.76 & 2.52 \\
\hline 0.11 & 0.00 & 0.03 & 0.18 & 0.18 & 0.19 & 0.17 & 0.19 \\
\hline 0.42 & 0.45 & 0.43 & 0.44 & 0.46 & 0.45 & 0.49 & 0.33 \\
\hline 0.33 & 0.23 & 0.53 & 0.33 & 0.23 & 0.27 & 0.32 & 0.28 \\
\hline 2.29 & 2.30 & 2.60 & 2.49 & 2.58 & .2 .74 & 2.66 & 2.94 \\
\hline 0.03 & 0.03 & 0.05 & 0.06 & 0.05 & 0.05 & 0.04 & 0.07 \\
\hline 2.60 & 2.28 & 1.58 & 1.89 & 1.95 & 1.58 & 1.83 & 1.71 \\
\hline 0.13 & 0.07 & 0.11 & 0.03 & 0.20 & 0.05 & 0.06 & 0.10 \\
\hline 0.24 & 0.11 & 0.08 & 0.10 & 0.01 & 0.00 & 0.06 & 0.11 \\
\hline 1.76 & 1.71 & 1.78 & 1.85 & 1.84 & 1.81 & 1.78 & 1.87 \\
\hline 3.79 & 4.91 & 4.68 & 4.35 & 3.89 & 4.91 & 4.23 & 4.15 \\
\hline
\end{tabular}

amphibolite in agmatitic mass $10:$ From amphibalite in small xenolith-like black 11-14: From From coarse-grained granodiorite, the main facies of the ōbatake and Gamano layered

biotites (OS2-4, YN1-1, YN3-1, YN10, YN3-2, YN3-3, OS4 and OS2-2) are higher in $\mathrm{H}_{2} \mathrm{O}$ but normal in $\mathrm{K}_{2} \mathrm{O}$. The $\mathrm{K}_{2} \mathrm{O}$ contents and microscopic inspection favour that they are free from weathering. This also is supported by their oxygen isotopic ratios which are sensitive to weathering (Honma, 1974, unpublished).

In all the biotites analysed, the total number of trivalent cations in octahedral site is less than 1.5 (the limit of the number for natural trioctahedral biotites according 
Table 1

Composition of

\begin{tabular}{|c|c|c|c|c|c|c|c|}
\hline lo. & 17 & 18 & 19 & 20 & 21 & 22 & 23 \\
\hline pecimen & YN 9-I & YN29-I & YN $4-1$ & YN 4-2 & $\mathrm{YN} \quad 3-3$ & YN $8-3$ & os $2-5$ \\
\hline $\mathrm{iO}_{2}$ & 35.22 & 34.90 & 32.98 & 34.15 & 32.65 & 33.83 & 33.01 \\
\hline $\mathrm{iO}_{2}$ & 3.60 & 3.50 & 3.50 & 3.60 & 3.73 & 3.16 & 3.66 \\
\hline${ }_{2} \mathrm{O}_{3}$ & 14.73 & 14.37 & 14.68 & 15.08 & 16.81 & 19.07 & 16.03 \\
\hline $\mathrm{e}_{2} \mathrm{O}_{3}$ & 1.74 & 2.42 & 4.72 & 3.21 & 2.76 & 1.83 & 2.75 \\
\hline$e 0$ & 20.11 & 22.62 & 20.80 & 22.15 & 20.72 & 20.54 & 19.96 \\
\hline no & 0.42 & 0.34 & 0.42 & 0.39 & 0.50 & 0.47 & 0.53 \\
\hline go & 8.52 & 6.84 & 6.03 & 6.10 & 6.35 & 5.92 & 6.35 \\
\hline $\mathrm{aO}$ & 0.40 & 0.62 & 0.49 & 0.65 & 0.18 & 0.42 & 0.67 \\
\hline $\mathrm{Na}_{2} \mathrm{O}$ & 0.32 & 0.47 & 0.33 & 0.30 & 0.59 & 0.35 & 0.74 \\
\hline $\mathrm{K}_{2} \mathrm{O}$ & 9.05 & 8.84 & 8.64 & 8.95 & 9.54 & 9.01 & 9.89 \\
\hline $\mathrm{H}_{2} \mathrm{O}(+)$ & 4.49 & 3.83 & 4.32 & 4.27 & 4.97 & 4.54 & 4.30 \\
\hline $\mathrm{H}_{2} \mathrm{O}(-)$ & 0.85 & 0.44 & 2.28 & 0.88 & 1.23 & 0.47 & 1.44 \\
\hline $\mathrm{P}_{2} \mathrm{O}_{5}$ & 0.00 & 0.00 & .00 & 0.01 & 0.01. & 0.00 & 0.02 \\
\hline ota & 99.45 & 99.19 & 99.19 & 99.74 & 100.04 & 99.61 & 99.35 \\
\hline
\end{tabular}

Number of Atoms on

\begin{tabular}{llllll|ll}
$\mathrm{Si}$ & 5.44 & 5.50 & 5.28 & 5.35 & 5.07 & 5.19 & 5.22 \\
$\mathrm{AI}$ & 2.56 & 2.50 & 2.72 & 2.65 & 2.93 & 2.91 & 2.78 \\
$\mathrm{Al}^{\mathrm{VI}}$ & 0.12 & 0.17 & 0.05 & 0.14 & 0.14 & 0.54 & 0.20 \\
$\mathrm{Ti}$ & 0.42 & 0.42 & 0.42 & 0.42 & 0.44 & 0.36 & 0.43 \\
$\mathrm{Fe}^{3+}$ & 0.20 & 0.29 & 0.57 & 0.38 & 0.32 & 0.21 & 0.33 \\
$\mathrm{Fe}^{2+}$ & 2.60 & 2.98 & 2.78 & 2.90 & 2.69 & 2.63 & 2.64 \\
$\mathrm{Mn}$ & 0.05 & 0.05 & 0.06 & 0.05 & 0.07 & 0.06 & 0.07 \\
$\mathrm{Mg}$ & 1.96 & 1.61 & 1.44 & 1.42 & 1.47 & 1.35 & 1.49 \\
$\mathrm{Ca}$ & 0.07 & 0.11 & 0.08 & 0.11 & 0.03 & 0.07 & 0.11 \\
$\mathrm{Na}$ & 0.10 & 0.14 & 0.10 & 0.09 & 0.18 & 0.10 & 0.23 \\
$\mathrm{~K}$ & 1.78 & 1.78 & 1.76 & 1.79 & 1.89 & 1.76 & 1.99 \\
$\mathrm{OH}$ & 4.62 & 4.02 & 4.61 & 4.47 & 5.15 & 4.65 & 4.53
\end{tabular}

17-19 : From coarse-grained granodiorite, the main facies of the Ōbatake and Gamano layered migmatitic facies in YN3-2 22-25: From the Okiura layered granite 26.27: From migmatitic granite 29 : From the Kibe granite 30 : From basic facies of the Towa granite 31 : From fine-

to Deer et al., 1962). However, in some of them, the number of cations in octahedral site is significantly less than the maximum number of six per formula unit. The strict layer charge relations, defined by
Foster (1960) and shown graphically by Deer et al. (1962), are much disturbed in these biotites.

Paragenesis of biotites and their $\mathrm{Al}_{2} \mathrm{O}_{3}$ contents 
(Continued)

Biotites

Analyst : K. Ikehara and H. Fukui

\begin{tabular}{rrrr|rrrr}
\multicolumn{1}{c}{24} & \multicolumn{1}{c}{25} & \multicolumn{1}{c}{26} & \multicolumn{1}{c}{27} & \multicolumn{1}{c}{28} & \multicolumn{1}{c}{29} & \multicolumn{1}{c}{30} & 31 \\
OS 4 & YN 15 & OS 2.2 & OS $2-3$ & YN 11 & YN 24 & OS 6 & YN $6-1$ \\
34.50 & 34.62 & 33.89 & 34.06 & 34.31 & 34.60 & 33.03 & n.d. \\
2.66 & 2.00 & 2.40 & 3.00 & 2.30 & 2.60 & 3.57 & 2.65 \\
17.41 & 17.44 & 19.12 & 19.14 & 16.02 & 18.07 & 14.25 & 18.85 \\
3.10 & 1.51 & 2.65 & 2.44 & 2.57 & 2.44 & 3.78 & \\
21.69 & 22.66 & 16.53 & 16.95 & 23.59 & 19.71 & 24.27 & $3(27.33)$ \\
0.42 & 0.49 & 0.59 & 0.51 & 0.45 & 0.47 & 0.45 & 0.97 \\
5.36 & 4.80 & 8.95 & 7.48 & 4.87 & 6.27 & 4.99 & 4.79 \\
0.43 & 1.09 & 0.39 & 0.43 & 1.53 & 0.74 & 0.33 & 0.12 \\
0.73 & 0.73 & 0.51 & 0.41 & 0.64 & 0.57 & 0.32 & 0.48 \\
8.02 & 8.73 & 9.61 & 9.03 & 9.10 & 9.42 & 9.11 & 9.48 \\
4.78 & 4.49 & 4.89 & 4.43 & 4.02 & 4.09 & 4.32 & $n . d$. \\
0.41 & 0.72 & 0.70 & 1.49 & 0.26 & 0.78 & 1.25 & $n . d$. \\
0.00 & 0.00 & 0.00 & 0.00 & 0.00 & 0.00 & 0.01 & 0.01 \\
99.51 & 99.28 & 100.23 & 99.37 & 99.66 & 99.76 & 99.68 &
\end{tabular}

Basis $(\mathrm{O}, \mathrm{OH})=24$

\begin{tabular}{llll|lll}
5.30 & 5.40 & 5.10 & 5.22 & 5.40 & 5.35 & 5.27 \\
2.70 & 2.60 & 2.90 & 2.78 & 2.60 & 2.65 & 2.68 \\
0.45 & 0.60 & 0.49 & 0.68 & 0.37 & 0.64 & 0.00 \\
0.31 & 0.23 & 0.27 & 0.35 & 0.27 & 0.31 & 0.43 \\
0.36 & 0.17 & 0.30 & 0.28 & 0.30 & 0.28 & 0.45 \\
2.78 & 2.95 & 2.08 & 2.17 & 3.11 & 2.55 & 3.24 \\
0.05 & 0.06 & 0.08 & 0.07 & 0.06 & 0.06 & 0.06 \\
1.22 & 1.12 & 2.01 & 1.17 & 1.14 & 1.44 & 1.19 \\
0.07 & 0.18 & 0.06 & 0.07 & 0.26 & 0.12 & 0.06 \\
0.22 & 0.22 & 0.15 & 0.12 & 0.19 & 0.17 & 0.10 \\
1.57 & 1.74 & 1.85 & 1.76 & 1.83 & 1.86 & 1.85 \\
4.89 & 4.66 & 4.91 & 4.53 & 4.22 & 4.21 & 4.59
\end{tabular}

granodiorites 20 : From biotite-rich schlieren in YN4-1 21 : From K-feldspar porphyroblastic facies of the Okiura layered granite associated with siliceous gneiss 28 : From the Murotsu grained, biotite granite

The biotites of the present study may be grouped into three types by their paragenesis, that is, biotites associated with hornblende, those with muscovite and those that lack both of them. Biotites from amphibolite are in intimate association with hornblende and those from sedimentary gneiss are with muscovite, whereas in granitic rocks, biotites occur in the three types of paragenesis. 

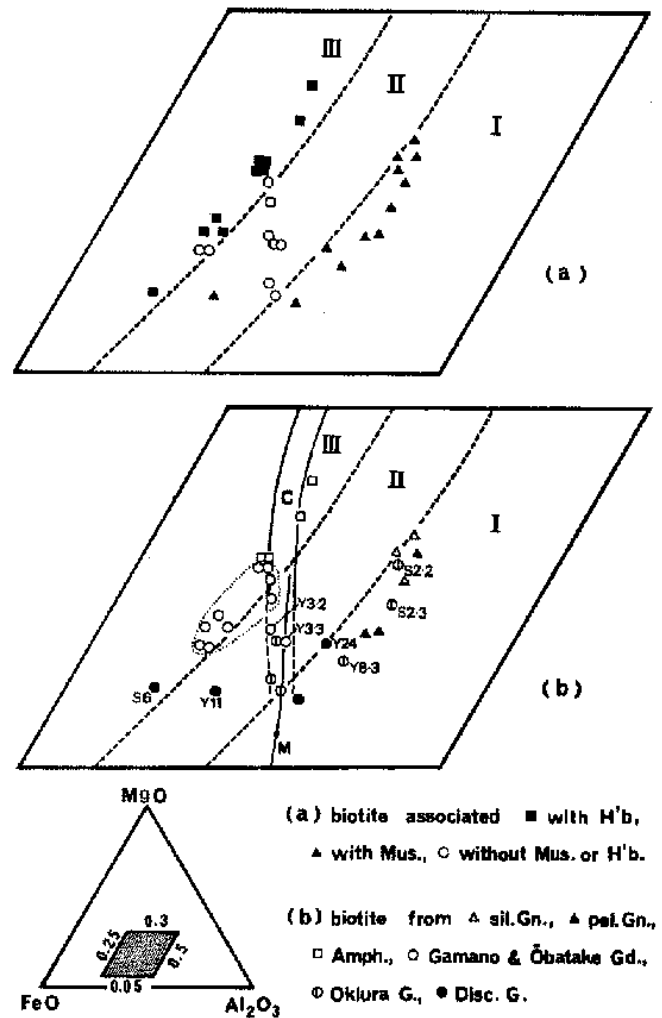

Fig. 1. The MgO-total iron as $\mathrm{FeO}-\mathrm{Al}_{2} \mathrm{O}_{\mathrm{a}}$ (weight per cent) diagram for biotites classified by paragenesis (a) and by type of the host rock (b). C: field for Caledonian plutonic biotites (Nockolds and Mitchel, 1948); M: trend of biotites from acid nembers of Murrumbidgee Batholith (Joyce, 1973); I, II and III are the fields defined by Nockolds (1947) for biotites from calc-alkaline igneous rocks associated with muscovite, without muscovite or hornblende and with hornblende respectively. $\mathrm{Y}: \mathrm{YN}$; $\mathrm{S}: \mathrm{OS}$

As is shown in Fig. 1a, the three types of biotites are distinct from each other in their relative $\mathrm{Al}_{2} \mathrm{O}_{3}$ content, each confining themselves in the three narrow fields defined by Nockolds (1947) for the corresponding biotites from calc-alkaline igneous rocks.

The distribution of $\mathrm{Al}$ between octahedral and tetrahedral sites in biotite is illustrated in Fig. 2. Both $\mathrm{Al}^{\mathrm{IV}}$ and $\mathrm{Al}^{\mathrm{vI}}$

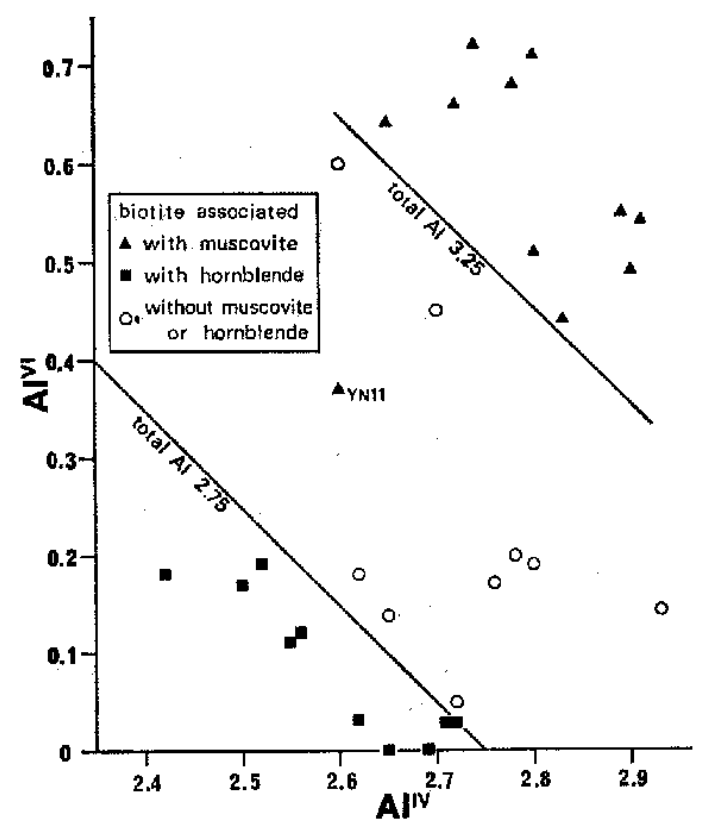

Fig. 2. The distribution of aluminium between octahedral and tetrahedral sites in biotite. Grouping of biotites by their paragenesis.

show only limited ranges of variation within each group of paragenesis. Inspection of Fig. 2 reveals that in biotites associated with muscovite, aluminium has a stronger site preferance to octahedral site than in other two groups.

As is shown in Fig. 3, the muscovitebearing rocks (sedimentary gneiss, migmatitic facies of the Okiura layered granite and many of the discordant granites) have excess aluminium to form normative corundum, whereas other two rocks, especially, those of homblende-biotite paragenesis, are deficient in aluminium over calcium, showing normative wollastonite. These facts strongly indicate that the paragenesis of the biotites, their $\mathrm{Al}_{2} \mathrm{O}_{3}$ contents and the partition of $\mathrm{Al}$ between octahedral and tetrahedral sites are, in most cases, controlled by the chemistry of their host rocks. 


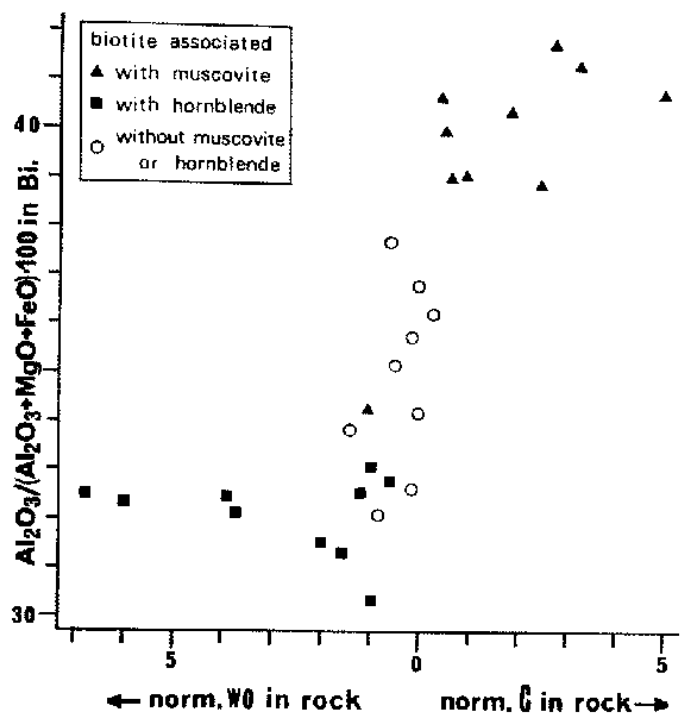

Fig. 3. Variation in $\mathrm{Al}_{2} \mathrm{O}_{3}$ content of biotite plotted as a function of normative wo or $C$ of the host rock. Grouping of biotites by their paragenesis.

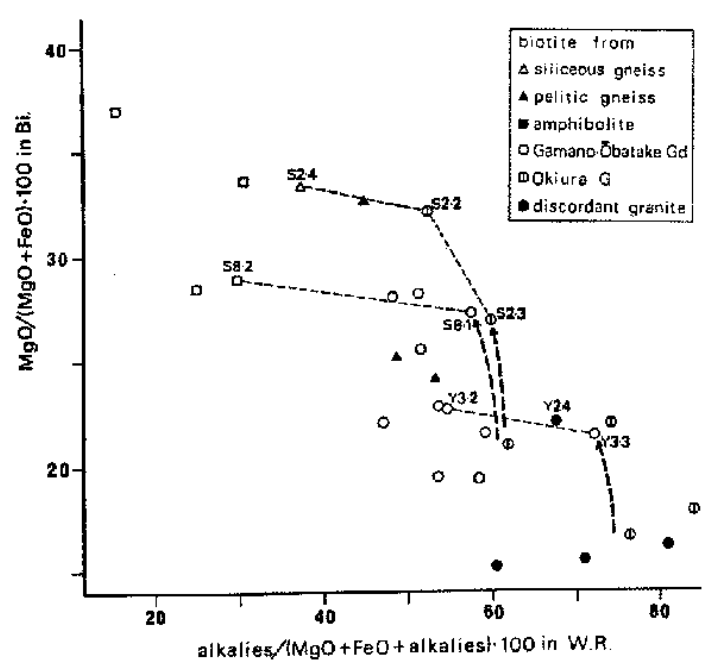

Fig. 4. Variation in the $\mathrm{MgO} / \mathrm{FeO}$ ratio in biotite vs. the content of alkalies of the host rock. Grouping of biotites by type of their host rocks. Dashed arrows show possible variation trends of granite during assimilation.

\section{The $\mathrm{MgO} / \mathrm{FeO}$ ratio in biotites}

Fig. $1 \mathrm{~b}$ indicates that $\mathrm{MgO} / \mathrm{FeO}$ ratios vary rather widely within each group, biotites from the metamorphic rocks having higher ratios than those from the granitic rocks.

Fig. 4 shows the variation in the $\mathrm{MgO} / \mathrm{FeO}$ ratio of biotites with solidification of magma or "granitization" of metamorphic rock. In this diagram, the $\mathrm{MgO} /$ $(\mathrm{MgO}+\mathrm{FeO})$ ratio of biotite is plotted against the alkalies/(alkalies $+\mathrm{MgO}+\mathrm{FeO}$ ) ratio of the host rock. The $\mathrm{SiO}_{2}$ content cannot be used as an index of "granitization," because "granitization" of siliceous gneiss causes complementary compositional changes including an increase in alkalies and a decrease in $\mathrm{SiO}_{2}$ and because $\mathrm{K}_{2} \mathrm{O}$, $\mathrm{Na}_{2} \mathrm{O}, \mathrm{MgO}$ and $\mathrm{CaO}$ in granoblastic amphibolite vary markedly regardless of the $\mathrm{SiO}_{2}$ content (Honma, 1974).

The $\mathrm{MgO} / \mathrm{FeO}$ ratio of biotites in this district shows a general trend of decrease with increasing contents of alkalies in the host rocks (Fig. 4). The ratio is similar to and varies in parallel with the host rocks (Fig. 5).

The latter trend is interpreted by the facts that the granitic rocks as well as the

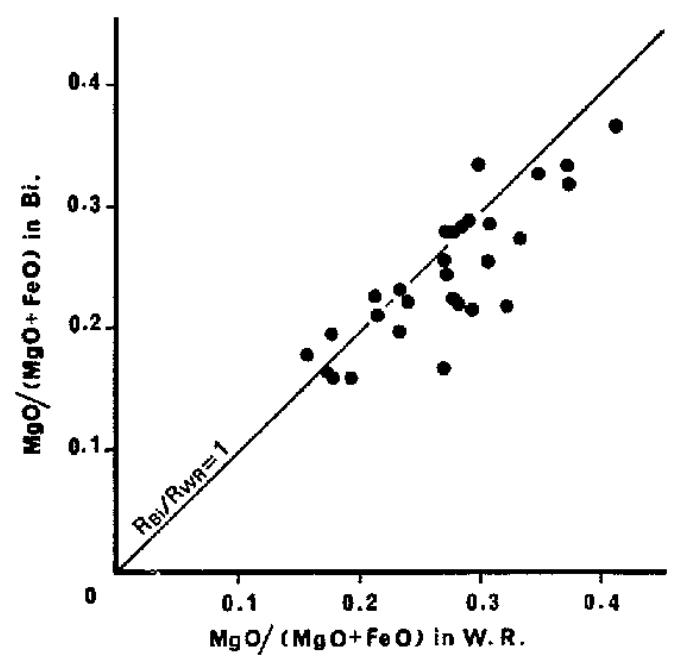

Fig. 5. Relationship of the $\mathrm{MgO} / \mathrm{FeO}$ ratio in biotite to that in the host rock. 


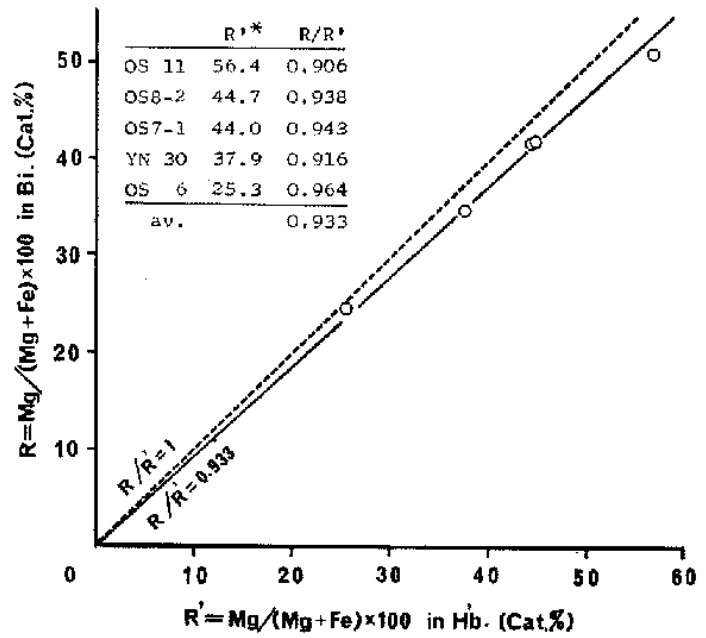

Fig. 6. Relationship of the $\mathrm{MgO} / \mathrm{FeO}$ ratio in biotite to that in coexisting homblende (*unpubished data of the present author).

metamorphic rocks of the present study almost lack magnetite and that, as is shown in Fig. 6, hornblende, the other major ferro-magnesian mineral, has almost the same $\mathrm{Mg} / \mathrm{Fe}$ ratio as biotite. Cordierite or garnet occurs only as a minor constituent in sedimentary gneisses and does not affect the $\mathrm{Mg} / \mathrm{Fe}$ ratio of biotite.

According to Kanisawa (1972), the

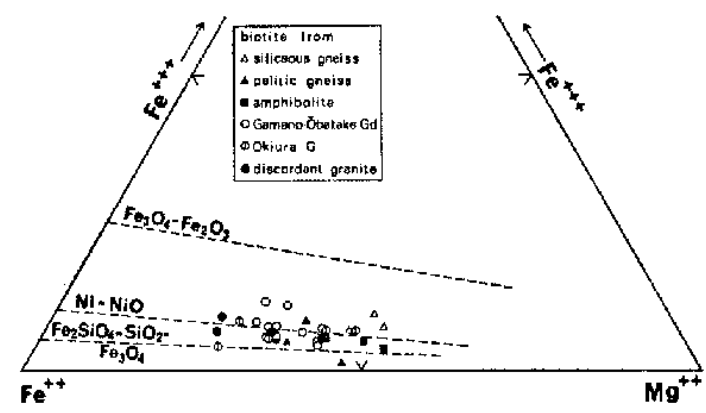

Fig. 7. The $\mathrm{Fe}^{+3}-\mathrm{F}^{+2}-\mathrm{Mg}^{+2}$ (cation per cent) diagram for biotites. Dashed lines represent compositions of "buffered" biotites in the ternary system $\mathrm{KFe}_{8}{ }^{+3} \mathrm{AISi}_{8} \mathrm{O}_{22} \mathrm{H}_{-1}-\mathrm{KFe}^{+2}{ }_{3}$ $\mathrm{AlSi}_{3} \mathrm{O}_{10}(\mathrm{OH})_{2}-\mathrm{KMg}_{3} \mathrm{AlSi}_{3} \mathrm{O}_{10}(\mathrm{OH})_{2}$ by Wones and Eugster (1965). Grouping of biotites by type of the host rock.
Ryōke granitic rocks of the Takato district, Central Japan, are distinctly higher in $(\mathrm{Mg} / \mathrm{Fe})_{\text {biotite }} /(\mathrm{Mg} / \mathrm{Fe})_{\text {hornblende }}$ than other granitic rocks. The high value of this ratio (close to 1) may be one of the chracteristic features of the Ryōke granitic rocks. Temperature and oxygen fugacity during the formation of biotites

In the $\mathrm{Fe}^{3+-}-\mathrm{Fe}^{2+}-\mathrm{Mg}^{2+}$ diagram shown in Fig. 7, many biotites studied are near Ni-NiO-buffered biotites estimated by Wones and Eugster (1965), According to them (Fig. 2 and Fig. 3), Ni-NiO-buffered biotites with $\mathrm{Fe} /(\mathrm{Fe}+\mathrm{Mg})$ of 0.75 are stable below $680^{\circ} \mathrm{C}$ at a total pressure of 1035 bars and below $710^{\circ} \mathrm{C}$ at 2070 bars. Oxygen isotopic equilibrium temperatures of quartz-biotite pairs from the granitic rocks fall in a narrow range between $600^{\circ}$ and $700^{\circ} \mathrm{C}$ (Honma, 1974, unpublished). These facts strongly suggest that the biotites were formed at a temperature between 600 and $700^{\circ} \mathrm{C}$ and under a low oxygen partial pressure close to the Ni-NiO-buffered system.

Tsusue and Ishihara (1974) mentioned that contents of opaque minerals of the Ryōke granitic rocks are low, reflecting a low oxygen fugacity during their formation. Observed evidence for intimate association and interaction of the layered granitic rocks with sedimentary gneiss suggests that a large amount of carbonaceous matter in the pelitic rocks should be responsible for the low oxygen fugacity during the formation of these granitic rocks and, hence, for the absence of magnetite in most of them. Progressive reduction of oxygen fugacity with increasing metamorphic grade has been suggested to occur owing to the removal of oxygen by graphite in pelitic rocks (Miyashiro, 1974). Biotites from the three types of granitic rocks 
As is seen from Fig. 1b, biotites from metamorphic rocks (amphibolite, pelitic gneiss and siliceous gneiss) are higher in $\mathrm{MgO} / \mathrm{FeO}$ than those from granitic rocks. Biotites from amphibolite are much poorer in $\mathrm{Al}_{2} \mathrm{O}_{3}$ than those from sedimentary gneisses.

Biotites from coarse-grained granodiorite, the main facies of the Obatake and Gamano layered granodionites, vary only in $\mathrm{MgO} / \mathrm{FeO}$ and follow the variation trend of the biotites from amphibolite. Almost all biotites from migmatitic facies of these granodiorites follow this trend, although a biotite from porphyroblastic K-feldsparbearing migmatitic granite (YN3-3, one of minor facies of the Öbatake and Gamano layered granodiorites) as well as one from migmatitic granodiorite (YN3-2) associated with this granite (YN3-3) deviate from the trend. $\mathrm{YN} 3-3$ is chemically equivalent to the main facies of the Okiura layered granite (Honma, 1974) and might have been formed from YN3-2 through metasomatic enrichment of normative $Q$ and or.

Biotites from the main facies of the Okiura layered granite (OS2-5, OS4 and YN15) follow a general trend characteristic of the biotites from acid members of Caledonian plutonic rocks (Nockolds and Mitchel, 1948) or Murrumbidgee Batholith (Joyce, 1973). The difference in the variation trend between the main facies of the Obatake and Gamano layered granodiorites and the Okiura layered granite given above may reflect difference in the mode of formation between these rocks.

Points for biotites from the discordant granites are much scattered and, except for those from the Kibe granite (YN 24), they are characteristically low in $\mathrm{MgO} /$ $\mathrm{FeO}$.
Biotites from migmatitic facies of the Okiura layered granite (OS2-2 and OS2-3) which forms thin bands in siliceous gneiss (OS2-4) differ much from those of the main facies of this granite. The siliceous gneiss should be responsible for distinctly high $\mathrm{MgO} / \mathrm{FeO}$ and $\mathrm{Al}_{2} \mathrm{O}_{3}$ in them. The high $\mathrm{Al}_{2} \mathrm{O}_{3}$ content of biotite from garnetbearing two-mica granite (YN8-3) alternating with siliceous gneiss may also reflect a contribution of alumina from the sedimentary gneisses.

A material balance calculation indicates that $\mathrm{MgO} / \mathrm{FeO}$ ratios of more mafic rocks which existed prior to the "granitization" must have been changed only slightly by addition of granitic materials. This is confirmed by Fig. 4 where only small differences in $\mathrm{MgO} /(\mathrm{MgO}+\mathrm{FeO})$ in biotites are recognized between the paired rocks: coarse-grained leucosome in agmatitic mass (OS8-1) and associated amphibolite (OS8-2); porphyroblastic K-feldsparbearing migmatitic granite (YN3-3) and associated medium-grained migmatitic granodionite (YN3-2). The biotites from the siliceous gneiss-migmatitic granite association (OS2-4, OS2-2 and OS2-3) show a similar trend as is shown in Fig. 4. This also is interpreted by the fact that the siliceous gneiss has a higher content of $(\mathrm{MgO}+\mathrm{FeO})$ relative to alkalies than the granitic magma.

On the other hand, the $\mathrm{MgO} /(\mathrm{MgO}+$ $\mathrm{FeO}$ ) ratio of granite must have changed markedly by assimilation of rocks which are high in $(\mathrm{MgO}+\mathrm{FeO})$ relative to alkalies. The trend of biotites from the Okiura layered granite may reflect that the sedimentary gneiss played a significant role in controlling the chemistry of some of this type of granites.

The trend of biotites from the Ōbatake 
and Gamano layered granodiorites indicates that $\mathrm{MgO}$ of the magma was used up by biotite and hornblende in earlier stages of crystallization. The low $\mathrm{MgO} / \mathrm{FeO}$ ratio in biotites from the discordant granites which are the later intrusives may similarly be interpreted.

\section{Concluding Remarks}

The relationship between composition and paragenesis defined by Nockolds (1947) for biotites from calc-alkaline igneous rocks hold for those from various kinds of rocks from highly metamorphic zone of the Yanai district including pelitic and siliceous gneisses, amphibolite, two types of syntectic layered granitic rocks and the discordant granites. The main difference in composition among the biotites of each paragenesis is in the content of $\mathrm{Al}_{2} \mathrm{O}_{3}$. Both $\mathrm{Al}^{\mathrm{tv}}$ and $\mathrm{Al}^{\mathrm{vI}}$ in the biotites of each paragenesis vary within limited ranges. It is found that both the $\mathrm{Al}_{2} \mathrm{O}_{3}$ content and paragenesis of these biotites are controlled by the chemistry of their host rocks. The similar relation is seen in the $\mathrm{MgO} / \mathrm{FeO}$ ratio between biotite and the host rock. These facts are in accord with the geological postulation that all the biotites were formed at roughly an equal P-T condition.

There is a marked difference in the content of $\mathrm{Al}_{2} \mathrm{O}_{3}$ in biotite between amphibolite and sedimentary gneiss. The biotites from the main facies of the Obatake and Gamano layered granodiorites follow a well-defined trend of biotites from the amphibolite without any significant variation in the relative content of $\mathrm{Al}_{2} \mathrm{O}_{3}$. This strongly supports the view that these layered granodiorites are magmatic in origin or, at least, sedimentary gneiss played no important role in the formation of the main facies of these granodiorites. On the other hand, unusually high contents of $\mathrm{Al}_{2} \mathrm{O}_{3}$ of biotites from some facies of the Okiura layered granite suggest a contribution from sedimentary gneiss to this granite.

Variation in $\mathrm{MgO} / \mathrm{FeO}$ ratio in the rocks of this district is distinctly reflected in the ratio in biotites; the ratios in biotites and their host rocks are similar to and vary in parallel with each other, decreasing with increasing alkalies in the host rocks. This may be due to: (1) interaction or exchange of materials between granitic magma and rocks which existed prior to its intrusion and (2) predominance of hornblende and biotite over other ferromagnesian minerals, the nearly equal partitioning of $\mathrm{MgO}$ and $\mathrm{FeO}$ between the two minerals and using up of $\mathrm{MgO}$ by biotite and homblende in earlier stages of crystallization.

\section{ACKNOWLEDGEMENTS}

I wish to express my sincere thanks to Prof. H. Sakai of this institute for his helpful criticism and valuable suggestions. The analytical work was carried out by Mrs. K. Ikehara and Mrs. H. Fukui of this institute. I am indebted also to Mrs. H. Yamawaku and Mr. H. Asada of this institute for their technical assistance.

This work was supported by Grant in Aid for Scientific Research from the Ministry of Education of Japan represented by Dr. M. Gorai under the title: The Origin and Evolution of Acid Magmas.

\section{REFERENGES}

Deer, W.A., Howie, R.A. and Zussman, J. (1962), Rock Forming Minerals, 3, Sheet Silicates. Longmans, London.

Engel, A.E.J, and Engel, C.G. (1960), Progressive 
metamorphism and granitization of the major paragneiss, Northwest Adirondack Mountains, New York. II: Mineralogy. Bult. Geol. Soc. Am. 71, 1-58.

Foster, M.D. (1960), Layer charge relations in the dioctahedral and trioctahedral micas. $A m$. Mineral., 45, 383-393.

Hayama, Y. (1964), Progressive metamorphisin of pelitic and psammitic rocks in the Komagane district, Nagano Pref., Central Japan. Jour. Fac. Sci. Univ. Tokyo, Sec. II, 15, 321-365.

Honma, H. (1974), Major element chemistry of metamorphic and granitic rocks of the Yanai district in the Ryouke belt. Jour. Japan. Assoc. Mir. Pety. Econ. Geol., 69, 193-204.

Joyce, A.S. (1973), Chemistry of the minerals of the granitic Murrumbidgee Batholith, Australian Capital Territory, Chem. Geol., 11, 271296.

Kanisawa, S. (1972), Coexisting biotites and hornblendes from some granitic rocks in southern Kitakami mountains, Japan. Jour. Japan. Assoc. Min. Pely. Econ. Geol., 67, 332-344.

Kojima, G. and Okamura, Y. (1968), On the Kitaoshima granite gneiss complex. Jour. Sci. Hiroshimra Univ., Ser. C, 5, 295-306.

Miyashiro, A. (1956), Data on garnet-biotite equilibria in some metamorphic rocks of the Ryotke zone. Jour. Geol. Soc. Japan, 55, 218-223.

Miyashiro, A. (1964), Oxidation and reduction in the Earth's crust with special reference to the role of graphite. Geochim. el Cosmochim. Acta, 28, 717-729.

Murakami, N. (1969), Two contrastive trends of evolution of biotite in granitic rocks. Jour. Japan. Assoc. Min. Petr. Econ. Geol., 62, 223248.

Nockolds, S.R. (1947), The relation between chemical composition and paragenesis in the biotite micas of igneous rocks. Am. Jour. Sci, , 245, $401-420$.
Nockolds, S.R. and Mitchel, R.L. (1948), The geochemistry of some Caledonian plutonic rocks: a study in the relationship between the major and trace elements of igneous rocks and their minerals. Trans. Roy. Soc. Edin., 61, 533-575.

Nureki, T. (1960), Structural investigation of the Ryōke metamorphic rocks of the area between Iwakuni and Yanai, southwestern Japan. Jour. Sic. Hiroshima Univ., Ser. C, 3, 69-141.

Okamura, Y. (1957), Structure of the Ryoke metamorphic and granodioritic rocks of the Yanai district, Yamaguchi Prefecture. Jour. Geol. Soc. Japan, 63, 684-697 (in Japanese).

ōki, Y. (1961), Metanorphism in the northern Kiso range, Nagano Prefecture, Japan. Japan. Jour. Geol. Geogr., 32, 479-496.

Ōki، Y., Ōki, S. and Shibata, H. (1962), The systematic analysis of silicate rocks using ion exchange resin. Bull. Chem, Soc. Japan, 35, 274276.

Shibata, H., Oba, N. and Shimoda, N. (1966), Bearing of aluminium in mafic minerals in plutonic and metamorphic rocks. Sci. Rep. Tökyō Kyōitur Univ., Ser. C, 9, 89-124.

Shibata, H., ōki, Y. and Sakakibara, Y. (1960), Chemical composition of Japanese granitic rocks in regard to petrographic provinces. Part VIT. Sci. Rep. Tôkyō Kyöiku Univ., Sec. C, 5, 1-23.

Tsusue, A. and Ishihara, S. (1974), The iron titanium axides in the granitic rocks of Southwest Japan. Mining Grol, 24, 13-30 (in Japanese).

Wenk, E. (1970), Distribution of Al between coexisting micas in metamorphic rocks from the Central Alps. Contr. Mineral. Petrol., 26, 5061.

Wones, D.R. and Eugster, H.P. (1965), Stability of biotites: Experiment, theory and application. Am. Mineral., 50, 1228-1272. 


\title{
柳井地方領家帯の变成岩類と花翮岩類中の黒雲母の化学的特徽
}

\author{
本 間 弘 次
}

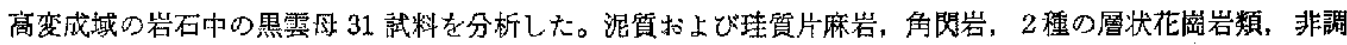

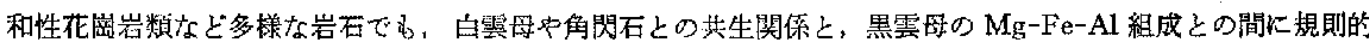

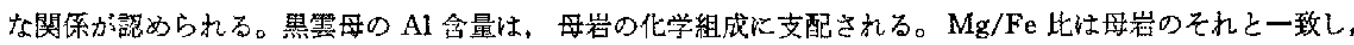

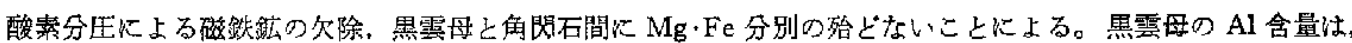
母岩の型ごとに一定で, 花崗岩類の一部の黑雲母の Al 含量が高いのは，片麻岩の影響によるものと考えられる。

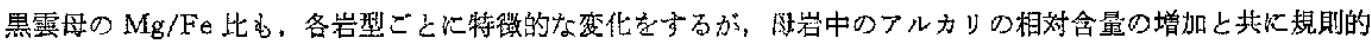

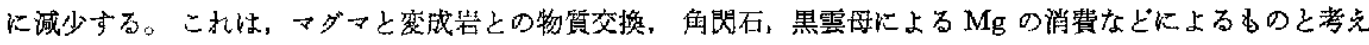
られる。 